\title{
BMJ Open Status of patient safety culture in Arab countries: a systematic review
}

\author{
Mustafa Elmontsri, Ahmed Almashrafi, Ricky Banarsee, Azeem Majeed
}

To cite: Elmontsri M, Almashrafi A, Banarsee R, et al. Status of patient safety culture in Arab countries: a systematic review. BMJ Open 2017:7:e013487

doi:10.1136/bmjopen-2016013487

- Prepublication history and additional material is available. To view please visit the journal (http://dx.doi.org/ 10.1136/bmjopen-2016013487).

Received 18 July 2016 Revised 16 November 2016 Accepted 16 December 2016

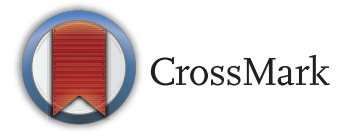

Department of Primary Care and Public Health, School of Public Health, Imperial College London, London, UK

Correspondence to Mustafa Elmontsri; m.elmontsri10@imperial.ac.uk

\section{ABSTRACT}

Objectives: To explore the status of patient safety culture in Arab countries based on the findings of the Hospital Survey on Patient Safety Culture (HSPSC).

Design: Systematic review.

Methods: We performed electronic searches of the MEDLINE, EMBASE, CINAHL, ProQuest and PsychINFO, Google Scholar and PubMed databases, with manual searches of bibliographies of included articles and key journals. We included studies that were conducted in the Arab countries that were focused on patient safety culture. 2 reviewers independently verified that the studies met the inclusion criteria and critically assessed the quality of the studies.

Results: 18 studies met our inclusion criteria. The review identified that non-punitive response to error is seen as a serious issue which needs to be improved. Healthcare professionals in the Arab countries tend to think that a 'culture of blame' still exists that prevents them from reporting incidents. We found an overall similarity between the reported composite score for dimension of teamwork within units in all of the reviewed studies. Teamwork within units was found to be better than teamwork across hospital units. All of the reviewed studies reported that organisational learning and continuous improvement was satisfactory as the average score of this dimension for all studies was $73.2 \%$. Moreover, the review found that communication openness seems to be a concerning issue for healthcare professionals in the Arab countries.

Conclusions: There is a need to promote patient safety culture as a strategy for improving the patient safety in the Arab world. Improving patient safety culture should include all stakeholders, like policymakers, healthcare providers and those responsible for medical education. This review was limited only to English language publications. The varied settings in which the HSPSC was used may have influenced the areas of strengths and weaknesses as healthcare workers' perception of safety culture may differ.

\section{INTRODUCTION}

For decades, human errors in complex systems have been a topic of debate due to their consequences. For example, system failures in the aviation industry cause great

\section{Strengths and limitations of this study}

The first systematic review carried out to report on the status of patient safety culture in Arab countries.

- The first systematic review to report on the use of the Hospital Survey on Patient Safety Culture in Arab countries.

- The review provides a comprehensive insight into the areas of strength and areas of improvement in relation to patient safety culture in Arab countries.

- Owing to the lack of relevant research literature in Arabic, this systematic review was restricted to English language publications only.

- The reported studies were conducted in different healthcare settings (eg, secondary and primary care) which might influence the perception of patient safety culture among healthcare workers.

publicity and are addressed very quickly because of the impact they have as they involve a large number of people and resources. In the healthcare sector, accidents can be deadly, but they do not attract as much attention as they affect fewer people at a time. Errors in healthcare settings began to draw public attention since the 1990s. 'To err is human' has triggered debate on the important issue of patient safety and a commitment to deliver high-quality, safe healthcare has become a policy goal of governments around the world over the past 15 years. $^{2}$ However, patients are continuing to suffer avoidable harm and substandard care. $^{3}$ According to the Institute of Medicine, safety is defined as 'the freedom of accidental injury'. On the other hand, the WHO defines patient safety as the 'reduction of risk of unnecessary harm associated with healthcare to an acceptable minimum'. Safety culture has now become a significant concept for healthcare organisations that are determined to improve patient safety. It is very important that the dynamics of this construct 'safety culture' are understood to produce positive change. Hence, it is vital that the underlying cultural factors present 
within an organisation should be known, so that the safety culture can be transformed. ${ }^{4}$ Several studies have investigated this area at organisational and individual levels in relation to safety culture with different measurements, techniques and modes, so that the contributing factors are understood. Thus, managers and leaders are encouraged to establish and sustain safety culture, as it is fundamental to total systems safety. ${ }^{5}$

Patient safety is based on continuous learning as there is a great need to report and learn from errors, accidents, near misses and adverse events, so that such events can be avoided in the future. The traditional approach to patient safety which is based on establishing mortality committees and scrutinising accidents ${ }^{6}$ can no longer be efficient as the healthcare system is becoming more complex. ${ }^{7}$ Major health organisations such as the WHO, National Patient Safety Foundation (NPSF), the Joint Commission International (JCI) and the Institute for Health Care Improvement (IHI) are encouraging healthcare organisations to develop a culture of safety as an effective strategy for sustainable safety improvement. ${ }^{8}$ A growing body of evidence indicates that the rate of medical errors and adverse events are associated with the attitudes of healthcare professionals towards safety. ${ }^{9}$ In this regard, patient safety culture, which is considered as a component of the organisational culture, includes the shared beliefs, attitudes, values, norms and behavioural characteristics of employees ${ }^{10}$ which will consequently influence the staff member attitudes and behaviours with regard to their organisation's ongoing patient safety performance. Frameworks, surveys and assessment tools have been developed over the past decade to help organisations measure and understand what type of culture exists in the organisation and also to identify areas of strength and gaps, so that factors that might improve or hinder improvement efforts can be identified. $^{411} 12$

\section{Patient safety in the Arab countries}

The developed and developing world are aiming to improve patient safety. ${ }^{13}$ Developing countries have been encouraged by the joint global initiative of the WHO and the World Alliance for Patient Safety (WAPS) to launch a concerted effort which will help in the assessment of the magnitude of the problem. One of the studies that evaluated patient safety in Arab countries has used the Patient Safety Friendly Hospital Initiative (PSFHI) standards. PSFHI is one of the initiatives of WHO that helps in supporting institutions in countries to launch a comprehensive patient safety programme, which was launched by the Eastern Mediterranean Regional Office of the WHO in 2007 to help improve the level of patient safety in the region. ${ }^{14}$ Ministries of health in seven developing countries have been assessed using the PSFHI which included Egypt, Jordan, Morocco, Pakistan, Sudan, Tunisia and Yemen. One hospital in each country was assessed against the PSFHI standards. The study found that none of the participating hospitals achieved a baseline score of $50 \%$ across the PSFHI standards. It was also found that commitment of the leadership and management are some of the key areas that are wanting in all institutions. Leadership is significant in patient safety as it recognises safe care as a system-related problem. ${ }^{15}$ Furthermore, it was found that patients in these countries are not being involved nor do they have a 'voice' in matters related to the care they receive. Another study which was carried out by the $\mathrm{WHO}^{16}$ found that no accreditation programmes are being adopted in the Eastern Mediterranean region. This has encouraged few countries in the region to develop and implement accreditation programmes to healthcare institutions. ${ }^{17}$ More importantly, it was reported that accreditation programmes have helped in improving the perception on the quality of patient care and patient safety in Saudi hospitals. ${ }^{18}$ Furthermore, a study was performed in hospitals in Egypt, Jordan, Kenya, Morocco, South Africa, Sudan, Tunisia and Yemen to assess the frequency and nature of adverse events to patients of these countries. The study found that of the 15548 records that were reviewed, $8.2 \%$ showed at least 1 adverse event. A range of $2.5-18.4 \%$ per country was found and $83 \%$ of these adverse events were judged to be preventable. The study also found that $30 \%$ of these events were associated with the death of the patient. ${ }^{19}$ It was reported that one in seven patients suffers harm in Palestinian hospitals. ${ }^{20}$ These statistics suggest that patient safety is a major concern for the health policy agenda in Arab countries and it is vital that the causes of harm to patients are identified and understood to develop strategies for improvement.

\section{The Hospital Survey on Patient Safety Culture}

One of the widely used and validated tools for measuring patient safety culture is the Hospital Survey on Patient Safety Culture (HSPSC) which was developed by the Agency for Healthcare Research and Quality (AHRQ) in the USA. ${ }^{21}$ This instrument consists of 12 dimensions as shown in online supplementary appendix A where each dimension consists of 3-4 survey items, totalling 42 survey items. The survey uses a fivepoint Likert response scale of agreement 'Strongly disagree to strongly agree' or frequency 'Never to Always'. The survey has been widely used in many countries worldwide, some of these are highlighted in online supplementary appendix B. The aim of this systematic review is to identify the overall status of patient safety culture in the Arab countries. The review also aims to explore the weaknesses, strengths and future opportunities for patient safety improvement in the Arab region.

\section{METHODS}

Search strategy

Electronic search of MEDLINE, EMBASE, CINAHL, ProQuest and PsychINFO, Google Scholar and PubMed 
databases, with manual searches of bibliographies of included articles and key journals. English and Arabic language studies published between January 2005 and December 2015 that used the HSPSC in a healthcare setting in any Arab country. Table 1 summarises the keywords that we used to execute the search.

\section{Inclusion and exclusion criteria}

Titles and abstracts were examined independently by two reviewers (ME and $\mathrm{AA}$ ) and were selected or excluded based on the following criteria:

Selection criteria: we included studies if they met the following criteria: (1) were concerned with any of the Arab countries mentioned in table 1, (2) used the HSPSC as an instrument for assessing patient safety culture, (3) were published in English or Arabic language and (4) were conducted in primary care, secondary or tertiary care settings.

Exclusion criteria: we excluded studies based on the following criteria: (1) studies that use tools other than the AHQR's HSPSC, (2) studies that are conducted in residential care facilities, (3) studies that involve patients, (4) studies that are conducted in non-Arab countries and (5) studies that have $<50$ participants. The flow chart in figure 1 illustrates our selection process.

\section{Data extraction}

We extracted data related to study setting, type and number of participants, composite scores for individual HSPSC categories and origin of the study.

\begin{tabular}{|c|c|}
\hline Field & Database \\
\hline Arab countries & $\begin{array}{l}\text { Mesh terms: Arab, Arab } \\
\text { countries, Arab worldAll fields: } \\
\text { Algeria or Bahrain or Egypt or } \\
\text { Iraq or Jordan or Kuwait or } \\
\text { Lebanon or Libya or Mauritania ol } \\
\text { Morocco or Oman or Palestine or } \\
\text { Qatar or Saudi Arabia or Sudan } \\
\text { or Syria or Tunisia or United Arab } \\
\text { Emirates (UAE) or Yemen, or } \\
\text { Arabic, or middle east }\end{array}$ \\
\hline Safety & $\begin{array}{l}\text { Safety or patient safety or patient } \\
\text { culture or hospital safety or } \\
\text { healthcare safety or safety } \\
\text { climate }\end{array}$ \\
\hline $\begin{array}{l}\text { Healthcare setting and } \\
\text { participants }\end{array}$ & $\begin{array}{l}\text { Hospital or nursing or healthcare } \\
\text { worker or teaching hospital or } \\
\text { primary healthcare, or clinic or } \\
\text { government hospital or private } \\
\text { hospital }\end{array}$ \\
\hline Assessment terms & Perception or assess or measure \\
\hline Survey instrument & $\begin{array}{l}\text { Hospital survey on patient safety } \\
\text { culture }\end{array}$ \\
\hline
\end{tabular}

\section{Quality appraisal}

We assessed the quality of included studies in our review through an adapted version of the Newcastle-Ottawa scale. ${ }^{36}$ The assessment can be found in online supplementary appendix C.

\section{RESULTS}

Eighteen papers met the inclusion criteria. The country with the most studies was Saudi Arabia (6 studies), while the rest were distributed as follows: Egypt (4 studies), Jordan (3 studies), Oman (2 studies), Kuwait (1 study), Lebanon ( 1 study) and Palestine (1 study). Of the 18 papers, 16 were conducted among hospital staff, while 2 were performed in a primary care setting. Collectively, the studies include a total of 17541 participants. Most selected studies had a response rate of above $60 \%$ except Ahmed et $a l,{ }^{37}$ AbuAlRub et $a l^{38}$ El-Jardali et $a l^{34}$ and Alahmadi ${ }^{35}$ which had a response rate of $59.2 \%$, $57 \%, 55.5 \%$ and $47.7 \%$, respectively. Only two studies used electronic and paper format to collect data, whereas the rest of the studies used paper format only.

\section{Type of participants}

We observed a wide variation in the type of participants in our reviewed studies. The majority of the studies have included multiple healthcare professionals. Out of these studies, seven have included non-clinical staff (eg, administrative, managerial staff). Seven studies have surveyed only nurses.

\section{Strengths and area of potential improvement}

Participants in the studies differed significantly in their positive response to different items in the survey. Surprisingly, there was a recurring theme among studies regarding perceptions of patient safety culture. Participants perceived non-punitive response to error to be the least practised in their organisation (table 2). This composite is defined as the extent to which staff feel that their mistakes and event reports are not held against them and that mistakes are not mentioned in their personnel files. On the other hand, organisation learning and continuous improvement were positively rated along with teamwork within units in most of the studies. Table 3 summarises the key strengths and areas of potential improvement based on each country; only three areas of strength and three areas that require improvements have been added in the table as these have received the highest and lowest ranking, respectively.

As noted in table 3 , the dimensions that were rated as strengths included organisational learning/continuous improvement, teamwork within units and hospital management support for patient safety. On the other hand, non-punitive response to error, staffing and communication openness were seen as areas that require further improvement in the perception of the participants in these studies. As seen in table 2, most of the studies reported that non-punitive response to error is the least 


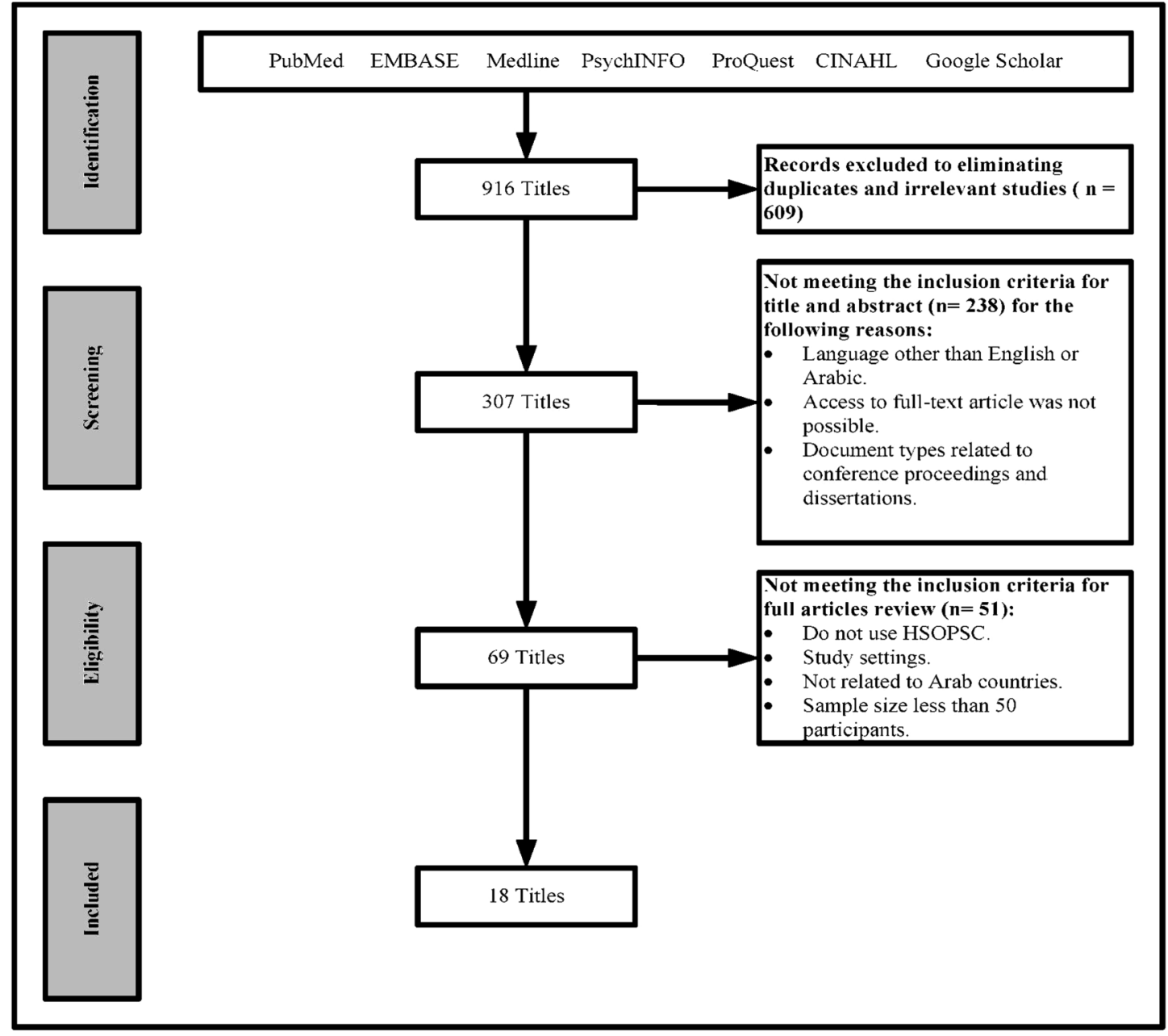

Figure 1 Selection process workflow.

positively ranked area irrespective of the type of the participants or the study sittings. The lowest mean score of the non-punitive response to error dimension was scored in Saudi Arabia, ${ }^{18}$ Palestine $^{39}$ and Egypt ${ }^{40}(16 \%, 17 \%$ and $19.5 \%$, respectively). Studies that were conducted in primary care settings ${ }^{41}{ }^{42}$ did not show any variation in terms of positive scores on the organisational learning and continuous improvement dimension when compared with the studies carried out in hospital settings as well as on the dimension of teamwork within units.

\section{DISCUSSION}

This review has focused on the status of patient safety culture in Arab countries to identify the areas of strength and the areas of concerns. Since the publication of the Institute of Medicine (IOM) report 'To err is human', ${ }^{2}$ patient safety culture has become a core element in improving patient safety. It was suggested in the IOM's report that any efforts which aim to improve patient safety culture should move away from a 'blame culture' and focus on removing 'error provoking' aspects of care delivery systems. ${ }^{2}$ The review showed that healthcare organisations in the Arab world are moving towards the need to assess and evaluate the patient safety culture of healthcare professionals to ensure that improvement strategies are being developed on evidence-based practices. It could also be argued that policymakers and practitioners in developing countries are becoming more aware of the risk of unsafe healthcare. $^{19}{ }^{52}$ The review showed that HSPSC is not widely used in the Arab world as HSPSC was only used in Saudi Arabia, Egypt, Jordan, Oman, Lebanon, Kuwait and Palestine. None of the reviewed studies were conducted in Arab countries that are located in North Africa. Interestingly, the English and Arabic versions of the HSPSC questionnaire were used in the selected studies. Eight studies have used the Arabic version, but only one study reported that the psychometric properties of Arabic version were validated. ${ }^{34}$

It was clear that healthcare staff in the Arab world are concerned about having a supportive organisational structure that encourages error reporting. There is growing evidence that suggests that the rate of medical errors and adverse events is associated with the attitudes and perceptions of professionals towards safety. ${ }^{9} 53$ Moreover, a study by Najjar $e t a \bar{l}^{54}$ which looked at the relationship between patient safety culture and adverse event rates in Palestinian hospitals found that 
Table 2 Per cent of positive score in each dimension

\begin{tabular}{|c|c|c|c|c|c|c|c|c|c|c|c|c|c|}
\hline \multirow[b]{2}{*}{ First author, year } & \multirow[b]{2}{*}{ Country } & \multicolumn{12}{|c|}{ Safety culture dimensions (percentage of positive score) ${ }^{\star}$} \\
\hline & & 1 & 2 & 3 & 4 & 5 & 6 & 7 & 8 & 9 & 10 & 11 & 12 \\
\hline Aboul-Fotouh, $2012^{40}$ & Egypt & 34.6 & 39.7 & 33.4 & 24.6 & 27.2 & 19.5 & 78.2 & 33.9 & 49.3 & 46.4 & 38 & 58.1 \\
\hline AbuAIRub, $2014^{38}$ & Jordan & 60.3 & 75 & 64.3 & 33.5 & 70.3 & 26.2 & 84.8 & 60.6 & 32.9 & 56.5 & 57.3 & 83.8 \\
\hline El-Jardali, $2010^{34}$ & Lebanon & 57.3 & 68.1 & 68.2 & 49.7 & 78.4 & 24.3 & 78.3 & 72.5 & 36.8 & 66.4 & 56.0 & 82.3 \\
\hline Alahmadi, $2010^{35}$ & Saudi Arabia & 60 & 77 & 63 & 61 & 74 & 22 & 87 & 59 & 27 & 70 & 50 & 84 \\
\hline El-Jardali, $2014^{43}$ & Saudi Arabia & 42.9 & 63.3 & 59.4 & 51.5 & 70.4 & 26.8 & 79.6 & 65.3 & 35.1 & 60.6 & 61.6 & 78.5 \\
\hline Al-Ahmadi, $2009^{44}$ & Saudi Arabia & 44.2 & 63.3 & 56.2 & 47.6 & 65.4 & 21.1 & 75.9 & 51.4 & 31.2 & 64 & 56.3 & 69.9 \\
\hline Al Awa, $2012^{18}$ & Saudi Arabia & 36 & 58 & 57 & 47 & 61 & 16 & 74 & 45 & 15 & 51 & 51 & 68 \\
\hline Ammouri, $2014^{45}$ & Oman & 49.7 & 68.7 & 58.8 & 57.7 & 25.2 & 21.4 & 81.1 & 50.7 & 27 & 60 & 66.1 & 83.4 \\
\hline Hamdan, $2013^{39}$ & Palestine & 36 & 46 & 35 & 48 & 37 & 17 & 62 & 43 & 38 & 56 & 44 & 71 \\
\hline Abdelhai, $2012^{46}$ & Egypt & 38 & 63 & 43.5 & 57 & 57.3 & 29.9 & 50 & 71.1 & 40 & 35.5 & 41.1 & 51.7 \\
\hline Ahmed, $2011^{37}$ & Egypt & 37.9 & 35.4 & 33.7 & 52.1 & 56.3 & 52.9 & 57.1 & 56.5 & 42.9 & 59.6 & 61.8 & 59.6 \\
\hline Saleh, $2015^{47}$ & Jordan & 46.1 & 46 & 37 & 44.3 & 44.5 & 30.7 & 49.2 & 43.3 & 30.4 & 43.3 & 43.8 & 49.8 \\
\hline Khater, $2014^{48}$ & Jordan & 49 & 59.5 & 69.1 & 41.7 & 53.5 & 21 & 68.1 & 60 & 34.5 & 57.9 & 41.7 & 78.8 \\
\hline Ghobashi, $2014^{41}$ & Kuwait & 45 & 62 & 32 & 47 & 67 & 24 & 75 & 61 & 41 & 53 & 63 & 82 \\
\hline Aboshaiqah, $2013^{49}$ & Saudi Arabia & 36 & 67 & 61 & 22 & 90 & 49 & 82 & 52 & 54 & 49 & 55 & 70 \\
\hline Aljabri, $2012^{50}$ & Saudi Arabia & 51 & 71 & 57 & 51 & 73 & 22 & 79 & 57 & 31 & 67 & 60 & 77 \\
\hline Al-Mandhari, $2014^{51}$ & Oman & 54 & 62 & 65 & 44 & 67 & 25 & 84 & 53 & 30 & 60 & 64 & 83 \\
\hline Mohamed, $2015^{42}$ & Egypt & 66.7 & 66.7 & 60 & 75 & 80 & 66.7 & 73.3 & 60 & 60 & 75 & 70 & 80 \\
\hline
\end{tabular}

departments with positive patient safety culture had lower rates of adverse events. In this regard, many developed countries have realised the importance of improving personnel safety behaviours to achieve high safety and reliability in addition to exploiting modern technology and advanced managerial systems. ${ }^{55}$ Non-punitive response to error has been negatively rated by all participants in all countries which suggests that a culture of medical dominance exists in the organisational structures of the Arab health systems. This medical dominance will also have influence on the interprofessional relationships between the healthcare staff as argued by Adamson et $a l^{56}$ The success or failure of team-based work systems implementation has been linked to effective leadership which is a key variable for the functioning of teams. ${ }^{57} 58$ To ensure safe and efficient work medical teams, interactive human factors such as communication, supervision or team structure were considered vital to achieve that. ${ }^{59}$ On the other hand, lack of coordinated care or team work failure and breakdowns in communication will result in an unfavourable outcome for the patient. ${ }^{53}$ There is a need to encourage team members through positive behaviour and feedback by leaders. ${ }^{61}$ Ensuring accountability with avoiding blame and negativity needs to be balanced by the leaders.

\section{System changes to improve patient safety}

Patients have a right to be protected by healthcare providers. $^{62}$ Systems that minimise the likelihood of errors while maximising the likelihood of intercepting these errors need to be established. ${ }^{63}$ An efficient operating mechanism that is dependent on the collaboration of the subparts to achieve an outcome is what describes the system approach to patient safety. ${ }^{64}$ Provider organisations across different care settings, policymakers, regulators, educational institutions and patients are the subparts of the patient safety system. ${ }^{64}$ The rate of errors in complex systems such as those that deliver healthcare is influenced by many factors. A nested hierarchy of factors that determine the safety of a healthcare system have been suggested by Vincent et $a l^{65}$ The system factors related to work environment, institutional context, organisation and management, individual team members, tasks and patients. ${ }^{65}$ This could imply that improving work conditions would involve improvements to interface design, to the physical environment, to the ergonomics of equipment or the reduction in distractions and interruptions which influence the propensity to error. ${ }^{7}$ A basic requirement of a safe system is using protocols, checklists and other reminders for patient and clinician interactions. ${ }^{7}$ The use of these aids would benefit making informed decisions and creating a culture of safety through complying with rules and procedures. A widely known and well-established systems-based model in patient safety research is known as 'Swiss Cheese Model' of safety ${ }^{66}$ in which it proposed that hazards within complex systems are prevented by a series of barriers. Thus, a systems-based approach to patient safety in Arab countries is highly needed.

\section{Patient safety reporting systems}

The review indicated that healthcare staff in the Arab world are not being encouraged to report incidents which can be investigated, so that lessons can be learnt. 
Table 3 Summary of the reviewed studies

\begin{tabular}{|c|c|c|c|c|c|c|c|}
\hline No & $\begin{array}{l}\text { First author, } \\
\text { year }\end{array}$ & Country & Setting & $\begin{array}{l}\text { Number of } \\
\text { participants }\end{array}$ & $\begin{array}{l}\text { Participants } \\
\text { type }\end{array}$ & Strength & Area of potential improvement \\
\hline 1 & $\begin{array}{l}\text { Aboul-Fotouh, } \\
2012^{40}\end{array}$ & Egypt & 1 teaching hospital & 510 & $\begin{array}{l}\text { Health } \\
\text { professional }\end{array}$ & $\begin{array}{l}\text { Organisational learning/ } \\
\text { continuous improvement } \\
\text { - Teamwork within unit } \\
\text { - Staffing }\end{array}$ & $\begin{array}{l}\text { Non-punitive response to } \\
\text { error } \\
\text { Handoffs and transition } \\
\text { Hospital management } \\
\text { support for patient safety }\end{array}$ \\
\hline 2 & $\begin{array}{l}\text { AbuAlRub, } \\
2014^{38}\end{array}$ & Jordan & 1 hospital & 57 & Nurses & $\begin{array}{l}\text { Organisational learning/ } \\
\text { continuous improvement } \\
\text { Teamwork within unit } \\
\text { Feedback and } \\
\text { communication about errors }\end{array}$ & $\begin{array}{l}\text { Non-punitive response to } \\
\text { error } \\
\text { Staffing } \\
\text { Handoffs and transition }\end{array}$ \\
\hline 3 & $\begin{array}{l}\text { El-Jardali, } \\
2010^{34}\end{array}$ & Lebanon & 68 hospitals & 6807 & $\begin{array}{l}\text { Clinical and } \\
\text { non-clinical staff }\end{array}$ & $\begin{array}{l}\text { Teamwork within unit } \\
\text { Hospital management } \\
\text { support for patient safety } \\
\text { Organisational learning/ } \\
\text { continuous improvement }\end{array}$ & $\begin{array}{l}\text { Non-punitive response to } \\
\text { error } \\
\text { Staffing } \\
\text { Hospital handoffs and } \\
\text { transitions }\end{array}$ \\
\hline 4 & $\begin{array}{l}\text { Alahmadi, } \\
2010^{35}\end{array}$ & $\begin{array}{l}\text { Saudi } \\
\text { Arabia }\end{array}$ & 13 hospitals & 223 & $\begin{array}{l}\text { Health } \\
\text { professionals }\end{array}$ & $\begin{array}{l}\text { Organisational learning/ } \\
\text { continuous improvement } \\
\text { Teamwork within unit } \\
\text { Feedback and } \\
\text { communication about errors }\end{array}$ & $\begin{array}{l}\text { Non-punitive response to } \\
\text { error } \\
\text { Staffing } \\
\text { Teamwork across hospital } \\
\text { units }\end{array}$ \\
\hline 5 & $\begin{array}{l}\text { El-Jardali, } \\
2014^{43}\end{array}$ & $\begin{array}{l}\text { Saudi } \\
\text { Arabia }\end{array}$ & 1 hospital & 2572 & $\begin{array}{l}\text { Clinical and } \\
\text { non-clinical staff }\end{array}$ & $\begin{array}{l}\text { Organisational learning/ } \\
\text { continuous improvement } \\
\text { Teamwork within unit } \\
\text { Hospital management } \\
\text { support for patient safety }\end{array}$ & $\begin{array}{l}\text { Non-punitive response to } \\
\text { error } \\
\text { Staffing } \\
\text { Communication openness }\end{array}$ \\
\hline 6 & $\begin{array}{l}\text { Al-Ahmadi, } \\
2009^{44}\end{array}$ & $\begin{array}{l}\text { Saudi } \\
\text { Arabia }\end{array}$ & $\begin{array}{l}9 \text { public hospitals and } 2 \\
\text { private }\end{array}$ & 1224 & $\begin{array}{l}\text { Clinical and } \\
\text { non-clinical staff }\end{array}$ & $\begin{array}{l}\text { Organisational learning/ } \\
\text { continuous improvement } \\
\text { Teamwork across hospital } \\
\text { units. } \\
\text { Supervisor/manager } \\
\text { expectations and action } \\
\text { promoting safety }\end{array}$ & $\begin{array}{l}\text { Handoffs and transition } \\
\text { Communication openness } \\
\text { Non-punitive response to } \\
\text { error }\end{array}$ \\
\hline 7 & Al Awa, $2012^{18}$ & $\begin{array}{l}\text { Saudi } \\
\text { Arabia }\end{array}$ & 1 hospital & 605 & Nurses & $\begin{array}{l}\text { Organisational learning/ } \\
\text { continuous improvement } \\
\text { Teamwork within unit } \\
\text { - Hospital management } \\
\text { support for patient safety }\end{array}$ & $\begin{array}{l}\text { Non-punitive response to } \\
\text { error } \\
\text { - Staffing } \\
\text { - Communication openness }\end{array}$ \\
\hline
\end{tabular}


Table 3 Continued

\begin{tabular}{|c|c|c|c|c|c|c|c|}
\hline No & $\begin{array}{l}\text { First author, } \\
\text { year }\end{array}$ & Country & Setting & $\begin{array}{l}\text { Number of } \\
\text { participants }\end{array}$ & $\begin{array}{l}\text { Participants } \\
\text { type }\end{array}$ & Strength & Area of potential improvement \\
\hline 8 & $\begin{array}{l}\text { Ammouri, } \\
2014^{45}\end{array}$ & Oman & 4 hospitals & 414 & Nurses & $\begin{array}{l}\text { Teamwork within unit } \\
\text { Organisational learning/ } \\
\text { continuous improvement } \\
\text { Feedback and } \\
\text { communication about errors }\end{array}$ & $\begin{array}{l}\text { - Non-punitive response to } \\
\text { error } \\
\text { Hospital management } \\
\text { support for patient safety } \\
\text { - Staffing }\end{array}$ \\
\hline 9 & Hamdan, $2013^{39}$ & Palestine & 11 hospitals & 1460 & $\begin{array}{l}\text { Clinical and } \\
\text { non-clinical staff }\end{array}$ & $\begin{array}{l}\text { Teamwork within unit } \\
\text { Organisational learning/ } \\
\text { continuous improvement } \\
\text { Supervisor/manager } \\
\text { expectations and action } \\
\text { promoting safety }\end{array}$ & $\begin{array}{l}\text { Non-punitive response to } \\
\text { error } \\
\text { - Frequency of events reported } \\
\text { - Communication openness }\end{array}$ \\
\hline 10 & $\begin{array}{l}\text { Abdelhai, } \\
2012^{46}\end{array}$ & Egypt & Teaching hospitals & 400 & $\begin{array}{l}\text { Health } \\
\text { professionals }\end{array}$ & $\begin{array}{l}\text { Feedback and } \\
\text { communication about error } \\
\text { Hospital management } \\
\text { support for patient safety } \\
\text { Hospital handoffs and } \\
\text { transitions }\end{array}$ & $\begin{array}{l}\text { Non-punitive response to } \\
\text { error } \\
\text { - Supervisor/manager } \\
\text { expectations and action } \\
\text { promoting safety } \\
\text { - Staffing }\end{array}$ \\
\hline 11 & Ahmed, $2011^{37}$ & Egypt & 2 university hospitals & 128 & Nurses & $\begin{array}{l}\text { Teamwork across hospital } \\
\text { units } \\
\text { Supervisor/manager } \\
\text { expectation and actions } \\
\text { promoting safety } \\
\text { Teamwork within units }\end{array}$ & $\begin{array}{l}\text { Frequency of reported events } \\
\text { - Feedback and } \\
\text { communication about error } \\
\text { Communication openness }\end{array}$ \\
\hline 12 & Saleh, $2015^{47}$ & Jordan & $\begin{array}{l}2 \text { public hospitals, } 2 \\
\text { private hospitals and } 1 \\
\text { teaching hospital }\end{array}$ & 242 & Nurses & $\begin{array}{l}\text { Teamwork within units } \\
\text { Organisational learning/ } \\
\text { continuous improvement } \\
\text { Communication openness }\end{array}$ & $\begin{array}{l}\text { Staffing } \\
\text { Non-punitive response to } \\
\text { error } \\
\text { Supervisor/manager } \\
\text { expectations and actions } \\
\text { promoting safety }\end{array}$ \\
\hline 13 & Khater, $2014^{48}$ & Jordan & $\begin{array}{l}15 \text { public hospitals, } 4 \\
\text { privates hospitals and } 2 \\
\text { teaching hospitals }\end{array}$ & 658 & Nurses & $\begin{array}{l}\text { Teamwork within units } \\
\text { Organisational learning/ } \\
\text { continuous improvement } \\
\text { - Frequency of events reported }\end{array}$ & $\begin{array}{l}\text { Non-punitive response to } \\
\text { error } \\
\text { Staffing } \\
\text { - Handoffs and transitions }\end{array}$ \\
\hline 14 & $\begin{array}{l}\text { Ghobashi, } \\
2014^{41}\end{array}$ & Kuwait & 4 primary care centres & 369 & $\begin{array}{l}\text { Clinical and } \\
\text { non-clinical }\end{array}$ & $\begin{array}{l}\text { Teamwork within units } \\
\text { Organisational learning/ } \\
\text { continuous improvement } \\
\text { Management support for } \\
\text { patient safety }\end{array}$ & $\begin{array}{l}\text { Non-punitive response to } \\
\text { error } \\
\text { - Frequency of events reported } \\
\text { - Staffing }\end{array}$ \\
\hline
\end{tabular}

Continued 


\begin{tabular}{|c|c|c|c|c|c|c|c|}
\hline No & $\begin{array}{l}\text { First author, } \\
\text { year }\end{array}$ & Country & Setting & $\begin{array}{l}\text { Number of } \\
\text { participants }\end{array}$ & $\begin{array}{l}\text { Participants } \\
\text { type }\end{array}$ & Strength & Area of potential improvement \\
\hline 15 & $\begin{array}{l}\text { Aboshaiqah, } \\
2013^{49}\end{array}$ & $\begin{array}{l}\text { Saudi } \\
\text { Arabia }\end{array}$ & 1 hospital & 498 & Nurses & $\begin{array}{l}\text { Hospital management } \\
\text { support for patient safety } \\
\text { - Organisational learning/ } \\
\text { continuous improvement } \\
\text { - Teamwork within units }\end{array}$ & $\begin{array}{l}\text { Hospital handoffs and } \\
\text { transitions } \\
\text { Communication openness } \\
\text { Non-punitive response to } \\
\text { error }\end{array}$ \\
\hline 16 & Aljabri, $2012^{50}$ & $\begin{array}{l}\text { Saudi } \\
\text { Arabia }\end{array}$ & 2 hospitals & 726 & $\begin{array}{l}\text { Health } \\
\text { professionals }\end{array}$ & $\begin{array}{l}\text { Organisational learning/ } \\
\text { continuous improvement } \\
\text { - Teamwork within units } \\
\text { - Hospital management } \\
\text { support for patient safety }\end{array}$ & $\begin{array}{l}\text { Non-punitive response to } \\
\text { error } \\
\text { Staffing } \\
\text { Hospital handoffs and } \\
\text { transitions }\end{array}$ \\
\hline 17 & $\begin{array}{l}\text { Al-Mandhari, } \\
2014^{51}\end{array}$ & Oman & 5 hospitals & 398 & $\begin{array}{l}\text { Clinical and } \\
\text { non-clinical }\end{array}$ & $\begin{array}{l}\text { Organisational learning/ } \\
\text { continuous improvement } \\
\text { Teamwork within units } \\
\text { Management support for } \\
\text { patient safety }\end{array}$ & $\begin{array}{l}\text { Non-punitive response to } \\
\text { error } \\
\text { Staffing } \\
\text { Handoffs and transitions }\end{array}$ \\
\hline 18 & $\begin{array}{l}\text { Mohamed, } \\
2015^{42}\end{array}$ & Egypt & 28 primary health centres & 250 & $\begin{array}{l}\text { Clinical and } \\
\text { non-clinical }\end{array}$ & $\begin{array}{l}\text { Teamwork within units } \\
\text { Management support for } \\
\text { patient safety } \\
\text { Supervisor expectations and } \\
\text { actions promoting safety }\end{array}$ & $\begin{array}{l}\text { Staffing } \\
\text { Frequency of events reported } \\
\text { Non-punitive response to } \\
\text { errors }\end{array}$ \\
\hline
\end{tabular}


This could be because such reporting systems are not being implemented by healthcare organisations in the region due to the lack of the required regulations to manage and promote patient safety as the case in developed countries, including the USA ${ }^{67}$ Hence, as argued by Leape ${ }^{68}$ adverse event-reporting systems will not be efficient within a punitive culture. Thus, there is a need for a fundamental culture change to ensure that all innovations which are introduced to improve patient safety can achieve their potential. More importantly, healthcare staff should have the opportunity to learn from such reporting systems by ensuring that there is a policy for effective feedback as that will help organisations learn from failures in the delivery of care. ${ }^{69}$ In other words, policymakers should work in collaboration with healthcare providers to ensure that reporting systems are being implemented and that staff are encouraged and supported to report any incidents which might have an impact on the patient's health. Leape $^{70}$ affirmed that patient safety reporting systems helps healthcare organisations to improve patient safety which is very significant to Arab countries as reported by this review. This is to ensure that when incidents occur in the workplace, organisations need to understand what happened and why so that the probability of recurrence is reduced and to figure out if the existing interventions are effective or not. ${ }^{71}$

\section{'Just' culture}

A prerequisite to achieving lasting improvement is the need to embed the goal of providing safe care in the culture of the organisation. ${ }^{72}$ Culture transformation is a complex endeavour as it evolves in response to past events, local conditions, the mood of the workforce and the character of the leadership. ${ }^{73}$ On the other hand, safety culture reflects the 'ability of individuals or organisations to deal with risks and hazards so as to avoid damage or losses and yet still achieve their goals'. ${ }^{66}$ Thus, organisations need to ensure that a positive patient safety culture is in place which encourages honest disclosure of information and that a sincere interest in rectifying the problems is demonstrated. ${ }^{72}$ It could also be assumed that healthcare organisations in the Arab world should move away from the culture of blame to a 'just' culture which encourages the acknowledgement of error so that learning from errors can be achieved. In other words, employees need to feel that they will not be punished or concealed for acknowledging errors. This could imply that positive safety culture will help in encouraging honesty and fostering learning by balancing the individual and organisational accountability to achieve better quality care.

\section{Education and regulation}

Milligan ${ }^{74}$ pointed out that a more fundamental change is required within the healthcare curricular in order to improve patient safety. This suggests that countries in the Arab world should focus on the need of providing training and education programmes to healthcare professionals and students on the importance of systems approach in creating a patient safety culture. The review indicated that organisational learning and continuous improvement has been ranked as one of the areas of strength in the Arab countries. However, there needs to be a holistic approach to patient safety management by ensuring that all relevant elements such as resources, training, education and policies are in place to create a sustainable culture of safety in the workplace. In the USA as a result of the IOM's report, the US Congress passed the Patient Safety and Quality Improvement Act in 2005 which aims at improving quality and safety through the collection and analysis of data on patient events. This shows that patient safety has to be improved by the involvement of all relevant stakeholders, including policymakers, healthcare providers and patients as well as their families.

\section{Communication and staffing}

The review indicated that staff in the healthcare sector in the Arab world perceived teamwork within units to be acceptable when compared with other dimensions of the survey. Teamwork efforts cannot be successful without open communication within the care team. Thus, it is vital that training programmes on teamwork and communication are provided to all staff, so that different disciplines in medicine are connected to improve team performance. It was revealed by Pronovost $e t a l^{75}$ that the Accreditation Council on Graduate Medical Education in the USA endorsed the inclusion of 'interpersonal and communication skills' in their core competencies in 1999. This shows that establishing interdisciplinary team training can help in improving patient safety as it will help in reducing the misunderstandings among individuals and teams which might have impact on the patient's care. Therefore, policymakers in the Arab countries should ensure that staff have the ability to speak up when there are concerns in the workplace as well as being able to consult and seeking help whenever it is needed to ensure highquality care is provided to all patients at all times. It was also found that level of staffing is a common issue that is shared by many Arab countries. Insufficient staffing is likely to cause stress as staff will be forced to work under pressure and for long hours. It is well evidenced that when nurses work more than 12 hours at one time, the risk of making an error increases significantly. ${ }^{76}$

\section{Limitations}

Owing to the lack of relevant research literature in Arabic, this systematic review was restricted to English language publications only that have been peer-reviewed. This could have limited other studies that have used the HSPSC. The reported studies were conducted in different healthcare settings (eg, secondary and primary care) which might influence the perception of patient safety culture among healthcare workers. In terms of the 
limitations of the review, responses to patients' safety culture items are likely to be dependent on the organisation where the interviews have been conducted. Intrinsic organisational culture elements such as management support, level of funding and size of the organisation can limit the generalisability of some of the reviewed studies. Another limitation is the fact that not all Arab countries have used the HSPSC which could also limit the generalisability of the reviewed studies. Moreover, the comparison between the reviewed studies may be difficult because of the variation in the type of participants (eg, nurses, doctors and administrators). Nurses may have a different perception of patient safety culture as they are in continuous contact with patients. We argue that mixed-method studies can help in enhancing the understanding of patient safety culture in the healthcare sector in Arab countries. The use of qualitative approaches such as semistructured interviews and focus groups with healthcare professionals, patients, policymakers and familiar can further identify the root causes of poor safety culture that exist in some healthcare settings. Qualitative findings can support quantitative findings and provide more insightful explanations about the challenges that face health systems in Arab countries.

\section{CONCLUSION}

Patient safety remains a global problem that affects the developed and developing countries. Healthcare organisations should focus on the need of assessing safety culture as that will provide basic understanding of the safety-related perceptions of their staff. Safety culture assessment tools can help healthcare organisations in identifying the areas for improvement. It is also very important that policymakers in the Arab countries establish a just culture in the workplace where employees should be encouraged to report any adverse events, errors, incidents or near misses so that lessons can be learnt. More importantly, safety culture should be assessed on a regular basis to evaluate the effectiveness of patient safety programmes and interventions. Healthcare leaders, researchers and legislators in the Arab countries need to realise that patient safety is a serious public health concern which costs lives. This review has identified that non-punitive response to error is seen as a serious issue which needs to be improved as healthcare professionals in the Arab countries tend to think that a 'culture of blame' still exists that prevents them from reporting incidents. Thus, policymakers need to ensure that legislations and regulations are introduced to encourage healthcare organisations to implement patient safety reporting systems which will help identify risks to patients and help healthcare organisations learn from their mistakes.

\section{Twitter Follow Mustafa Elmontsri @melmontsri}

Contributors ME and AA prepared the study protocol. RB helped MA and AA in designing the research strategy and selecting studies for inclusion. ME and
AA carried out the search, extracted the data and assessed the quality of the included studies. Data analysis was carried out under the supervision of RB and $A M$. ME and $A A$ wrote the manuscript that was then revised by RB and AM. The final version of the manuscript has been approved by all authors.

Funding This review was part of ME's PhD research which was funded by the Government of Libya. The Department of Primary Care and Public Health at Imperial College London is grateful for support from the NW London NIHR Collaboration for Leadership in Applied Health Research and Care (CLAHRC), the Imperial NIHR Biomedical Research Centre and the Imperial Centre for Patient Safety and Service Quality (CPSSQ).

Competing interests None declared.

Provenance and peer review Not commissioned; externally peer reviewed.

Data sharing statement No additional data are available.

Open Access This is an Open Access article distributed in accordance with the terms of the Creative Commons Attribution (CC BY 4.0) license, which permits others to distribute, remix, adapt and build upon this work, for commercial use, provided the original work is properly cited. See: http:// creativecommons.org/licenses/by/4.0/

\section{REFERENCES}

1. Wong J, Beglaryan $\mathrm{H}$, Association $\mathrm{OH}$. Strategies for hospitals to improve patient safety: a review of the research. Change Foundation, 2004.

2. Kohn LT, Corrigan JM, Donaldson MS. To err is human: building a safer health system. National Academies Press, 2000.

3. Dixon-Woods M, Baker R, Charles $\mathrm{K}$, et al. Culture and behaviour in the English National Health Service: overview of lessons from a large multimethod study. BMJ Qual Saf 2014;23:106-15.

4. Nieva VF, Sorra J. Safety culture assessment: a tool for improving patient safety in healthcare organizations. Qual Saf Health Care 2003;12(Suppl 2):ii17-23.

5. Gandhi TK, Berwick DM, Shojania KG. Patient safety at the crossroads. JAMA 2016;315:1829-30.

6. Deilkås $\mathrm{E}$, Hofoss D. Patient safety culture lives in departments and wards: multilevel partitioning of variance in patient safety culture. BMC Health Serv Res 2010;10:812.

7. Nolan TW. System changes to improve patient safety. BMJ 2000;320:771-3.

8. Azimi L, Tabibi SJ, Maleki MR, et al. Influence of training on patient safety culture: a nurse attitude improvement perspective. Int J Hosp Res 2012;1:51-6.

9. Bonner AF, Castle NG, Men A, et al. Certified nursing assistants' perceptions of nursing home patient safety culture: is there a relationship to clinical outcomes? J Am Med Dir Assoc 2009;10:11-20.

10. Fleming $\mathrm{M}$, Wentzell $\mathrm{N}$. Patient safety culture improvement tool: development and guidelines for use. Healthc Q 2008;11:10-5

11. Colla JB, Bracken AC, Kinney ML, et al. Measuring patient safety climate: a review of surveys. Qual Saf Health Care 2005;14:364-6.

12. Morello RT, Lowthian JA, Barker AL, et al. Strategies for improving patient safety culture in hospitals: a systematic review. BMJ Qual Saf 2013;22:11-18.

13. Donaldson L, Philip P. Patient safety: a global priority. Bull World Health Organ 2004:82:892-2.

14. Siddiqi S, Elasady R, Khorshid I, et al. Patient safety friendly hospital initiative: from evidence to action in seven developing country hospitals. Int J Qual Health Care 2012;24:144-51.

15. Clarke JR, Lerner JC, Marella W. The role for leaders of health care organizations in patient safety. Am J Med Qual 2007;22:311-8.

16. World Health Organization. Quality and Accreditation in Health Care Services: A Global Review. Geneva: World Health Organization, 2003, http://www.who.int/entity/hrh/documents/en/quality accreditation.pdf (accessed 10 Jun 2016).

17. El-Jardali F. Hospital accreditation policy in Lebanon: its potential for quality improvement. J Med Liban 2006;55:39-45.

18. Al Awa B, Jacquery A, Almazrooa A, et al. Comparison of patient safety and quality of care indicators between pre and post accreditation periods in King Abdulaziz University Hospital. Res J Med Sci 2011;5:61-6.

19. Wilson RM, Michel $\mathrm{P}$, Olsen S, et al. Patient safety in developing countries: retrospective estimation of scale and nature of harm to patients in hospital. BMJ 2012;344:e832.

20. Najjar S, Hamdan M, Euwema MC, et al. The Global Trigger Tool shows that one out of seven patients suffers harm in Palestinian 
hospitals: challenges for launching a strategic safety plan. Int J Qual Health Care 2013;25:640-7.

21. Sorra J, Nieva V. Reliability and Validity of the Hospital Survey on Patient Safety. Westat: Rockville, MD; 2006.

22. Olsen E. Reliability and validity of the Hospital Survey on Patient Safety Culture at a Norwegian hospital. Quality and Safety Improvement Research: Methods and Research Practice from the International Quality Improvement Research Network (QIRN), 2008:173-86.

23. Pfeiffer Y, Manser T. Development of the German version of the Hospital Survey on Patient Safety Culture: dimensionality and psychometric properties. Saf Sci 2010;48:1452-62.

24. Smits M, Christiaans-Dingelhoff I, Wagner C, et al. The psychometric properties of the 'Hospital Survey on Patient Safety Culture' in Dutch hospitals. BMC Health Serv Res 2008;8:1.

25. Hellings J, Schrooten W, Klazinga N, et al. Challenging patient safety culture: survey results. Int $J$ Health Care Qual Assur 2007;20:620-32.

26. Bagnasco A, Tibaldi L, Chirone $\mathrm{P}$, et al. Patient safety culture: an Italian experience. J Clin Nurs 2011;20:1188-95.

27. Waterson P, Griffiths P, Stride C, et al. Psychometric properties of the Hospital Survey on Patient Safety Culture: findings from the UK. Qual Saf Health Care 2010;19:e2.

28. Sarac C, Flin R, Mearns K, et al. Hospital survey on patient safety culture: psychometric analysis on a Scottish sample. BMJ Qual Saf 2011;20:842-8.

29. Naijar S, Hamdan M, Baillien E, et al. The Arabic version of the hospital survey on patient safety culture: a psychometric evaluation in a Palestinian sample. BMC Health Serv Res 2013;13:1.

30. Bodur S, Filiz E. Validity and reliability of Turkish version of 'Hospital Survey on Patient Safety Culture' and perception of patient safety in public hospitals in Turkey. BMC Health Serv Res 2010;10:28.

31. Robida A. Hospital survey on patient safety culture in Slovenia: a psychometric evaluation. Int J Qual Health Care 2013;25:469-75.

32. Hedsköld M, Pukk-Härenstam K, Berg E, et al. Psychometric properties of the hospital survey on patient safety culture, HSOPSC applied on a large Swedish health care sample. BMC Health Serv Res 2013;13:1.

33. Nie $\mathrm{Y}, \mathrm{Mao} \mathrm{X}, \mathrm{Cui} \mathrm{H}$, et al. Hospital survey on patient safety culture in China. BMC Health Serv Res 2013;13:1.

34. El-Jardali F, Jaafar M, Dimassi $\mathrm{H}$, et al. The current state of patient safety culture in Lebanese hospitals: a study at baseline. Int J Qual Health Care 2010;22:386-95.

35. Alahmadi $\mathrm{H}$. Assessment of patient safety culture in Saudi Arabian hospitals. Qual Saf Health Care 2010;19:e17.

36. Wells G, Shea B, O'connell D, et al. The Newcastle-Ottawa Scale (NOS) for assessing the quality of nonrandomised studies in metaanalyses. Ottawa, ON: Ottawa Hospital Research Institute; 2000. www.ohri.ca/programs/clinical_epidemiology/oxford.asp (accessed 10 Jun 2016)

37. Ahmed NG, Adam SM, Abd Al-Moniem II. Patient safety: assessing nurses' perception and developing an improvement plan. Life Sci $J$ 2011;8:53-64.

38. AbuAIRub RF, Abu Alhijaa EH. The impact of educational interventions on enhancing perceptions of patient safety culture among Jordanian senior nurses. Nurs Forum 2014;49:139-50.

39. Hamdan M, Saleem AA. Assessment of patient safety culture in Palestinian public hospitals. Int J Qual Health Care 2013;25:167-75.

40. Aboul-Fotouh A, Ismail NA, EzElarab HS, et al. Assessment of patient safety culture among health-care providers at a teaching hospital in Cairo, Egypt. East Mediterr Health J 2012;18:372.

41. Ghobashi MM, El-ragehy HAG, Ibrahim HM, et al. Assessment of Patient Safety Culture in Primary Health Care Settings in Kuwait. Epidemiol Biostat Public Health 2014;11:1-9.

42. Mohamed AM, Ali MS, Gewaifel Gl. Assessment of patient safety culture in primary healthcare services in Alexandria, Egypt. Glob $J$ Epidemiol Public Health 2015;2:5-14.

43. El-Jardali F, Sheikh F, Garcia NA, et al. Patient safety culture in a large teaching hospital in Riyadh: baseline assessment, comparative analysis and opportunities for improvement. BMC Health Serv Res 2014;14:1

44. Al-Ahmadi TA. Measuring patient safety culture in Riyadh's hospitals: a comparison between public and private hospitals. $J$ Egypt Public Health Assoc 2008;84:479-500.

45. Ammouri AA, Tailakh AK, Muliira JK, et al. Patient safety culture among nurses. Int Nurs Rev 2015;62:102-10.

46. Abdelhai R, Abdelaziz SB, Ghanem NS. Assessing patient safety culture and factors affecting it among health care providers at Cairo University Hospitals. J Am Sci 2012;8:277-85.
47. Saleh AM, Darawad MW, Al-Hussami M. The perception of hospital safety culture and selected outcomes among nurses: an exploratory study. Nurs Health Sci 2015;17:339-46.

48. Khater WA, Akhu-Zaheya LM, AL-Mahasneh SI, et al. Nurses' perceptions of patient safety culture in Jordanian hospitals. Int Nurs Rev 2015;62:82-91.

49. Aboshaiqah $\mathrm{AE}$, Baker OG. Assessment of nurses' perceptions of patient safety culture in a Saudi Arabia hospital. J Nurs Care Qual 2013;28:272-80.

50. Aljabri DI. Assessment of patient safety culture in Saudi hospitals: a baseline study in the eastern region. J King Abdulaziz Univ Med Sci 2012;19(1 Suppl):43-58.

51. Al-Mandhari A, Al-Zakwani I, Al-Kindi M, et al. Patient safety culture assessment in Oman. Oman Med J 2014;29:264.

52. Carpenter KB, Duevel MA, Lee PW, et al. Measures of patient safety in developing and emerging countries: a review of the literature. Qual Saf Health Care 2010;19:48-54.

53. Flin R, Fletcher G, McGeorge P, et al. Anaesthetists' attitudes to teamwork and safety. Anaesthesia 2003;58:233-42.

54. Najiar S, Nafouri N, Vanhaecht K, et al. The relationship between patient safety culture and adverse events: a study in Palestinian hospitals. Saf Health 2015;1:27.

55. Miller K, Riley W, Davis S. Identifying key nursing and team behaviours to achieve high reliability. $J$ Nurs Manag 2009;17:247-55.

56. Adamson BJ, Kenny DT, Wilson-Barnett J. The impact of perceived medical dominance on the workplace satisfaction of Australian and British nurses. J Adv Nurs 1995;21:172-83.

57. Avolio BJ, Jung DI, Murry W, et al. Building highly developed teams: Focusing on shared leadership processes, efficacy, trust, and performance. Adv Interdiscip Stud Work Teams 1996;3:173-209.

58. Day DV, Gronn P, Salas E. Leadership capacity in teams. Leadersh Q 2004;15:857-80.

59. Donchin Y, Gopher D, Olin M, et al. A look into the nature and causes of human errors in the intensive care unit. Crit Care Med 1995;23:294-300.

60. Kosnik LK. The new paradigm of crew resource management: just what is needed to reengage the stalled collaborative movement? Jt Comm J Qual Patient Saf 2002;28:235-41.

61. Cole $\mathrm{E}$, Crichton $\mathrm{N}$. The culture of a trauma team in relation to human factors. J Clin Nurs 2006;15:1257-66.

62. Spath PL. Error reduction in health care: a systems approach to improving patient safety. J Nurs Regul 2012;2:60.

63. Carayon P, Hundt A, Karsh BT, et al. Work system design for patient safety: the SEIPS model. Qual Saf Health Care 2006;15(Suppl 1): i50-8.

64. Pronovost P, Ravitz A, Stoll R, et al. Transforming Patient Safety: A Sector-Wide Systems Approach: Report of the WISH Patient Safety Forum 2015: Qatar: World Innovation Summit for Safety, 2015.

65. Vincent C, Taylor-Adams S, Stanhope N. Framework for analysing risk and safety in clinical medicine. BMJ 1998;316:1154-7.

66. Reason J. Safety paradoxes and safety culture. Inj Contr Saf Promot 2000;7:3-14.

67. Liang BA, Riley W, Rutherford W, et al. The Patient Safety and Quality Improvement Act of 2005: provisions and potentia opportunities. Am J Med Qual 2007;22:8-13.

68. Leape LL. Error in medicine. JAMA 1994;272: 1851-7.

69. Benn J, Koutantji M, Wallace L, et al. Feedback from incident reporting: information and action to improve patient safety. Qual Saf Health Care 2009;18:11-21.

70. Leape LL. Reporting of adverse events. N Engl J Med 2002;347:1633-8.

71. Vincent C. Understanding and responding to adverse events. N Engl $J$ Med 2003;348:1051-6.

72. Waring JJ. Beyond blame: cultural barriers to medical incident reporting. Soc Sci Med 2005;60:1927-35.

73. Reason J. Achieving a safe culture: theory and practice. Work Stress 1998;12:293-306

74. Milligan FJ. Establishing a culture for patient safety-the role of education. Nurse Educ Today 2007;27:95-102.

75. Pronovost $\mathrm{P}$, Berenholtz S, Dorman T, et al. Improving communication in the ICU using daily goals. J Crit Care 2003;18:71-5

76. Rogers AE, Hwang WT, Scott LD, et al. The working hours of hospital staff nurses and patient safety. Health Aff (Millwood) 2004;23:202-12. 